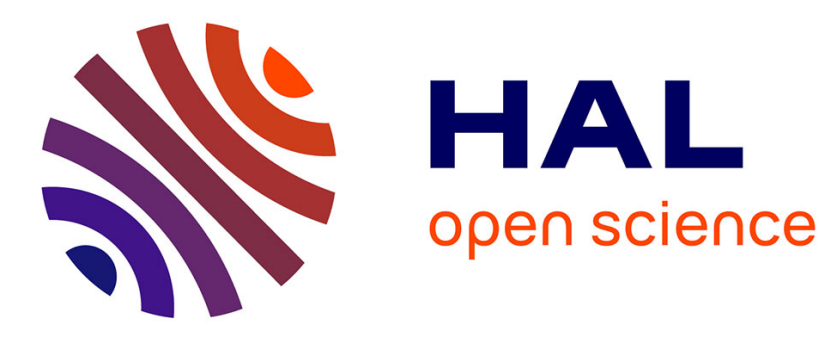

\title{
Ovipositor morphology correlates with life history evolution in agaonid fig wasps
}

Larissa Galante Elias, Finn Kjellberg, Fernando Henrique Antoniolli Farache, Eduardo A.B. Almeida, Jean-Yves Rasplus, Astrid Cruaud, Yan-Qiong Peng, Da-Rong Yang, Rodrigo Augusto Santinelo Pereira

\section{To cite this version:}

Larissa Galante Elias, Finn Kjellberg, Fernando Henrique Antoniolli Farache, Eduardo A.B. Almeida, Jean-Yves Rasplus, et al.. Ovipositor morphology correlates with life history evolution in agaonid fig wasps. Acta Oecologica, 2018, 90, pp.109-116. 10.1016/j.actao.2017.10.007 . hal-02332942

\section{HAL Id: hal-02332942 \\ https://hal.science/hal-02332942}

Submitted on 25 Oct 2019

HAL is a multi-disciplinary open access archive for the deposit and dissemination of scientific research documents, whether they are published or not. The documents may come from teaching and research institutions in France or abroad, or from public or private research centers.
L'archive ouverte pluridisciplinaire HAL, est destinée au dépôt et à la diffusion de documents scientifiques de niveau recherche, publiés ou non, émanant des établissements d'enseignement et de recherche français ou étrangers, des laboratoires publics ou privés. 
Ovipositor morphology correlates with life history evolution in agaonid fig wasps

Larissa Galante Elias ${ }^{\mathrm{a}, *}$, Finn Kjellberg ${ }^{\mathrm{b}}$, Fernando Henrique Antoniolli Farache ${ }^{\mathrm{a}}$, Eduardo A.B. Almeida ${ }^{\mathrm{a}}$, Jean-Yves Rasplus ${ }^{\mathrm{c}}$, Astrid Cruaud ${ }^{\mathrm{c}}$, Yan-Qiong Peng ${ }^{\mathrm{d}}$, Da-Rong Yang ${ }^{\mathrm{d}}$, Rodrigo Augusto Santinelo Pereira ${ }^{\mathrm{a}}$

${ }^{a}$ Department of Biology, FFCLRP, University of Sao Paulo, Av. Bandeirantes, 3900, 14040903, Ribeirao Preto, Sao Paulo, Brazil ${ }^{\text {b }}$ CEFE UMR 5175, CNRS - Université de Montpellier - Université Paul-Valéry Montpellier - EPHE - IRD, 1919 Route de Mende, 34293, Montpellier, Cedex 5, France ${ }^{\mathrm{c}}$ INRA - UMR 1062 CBGP (INRA/IRD/CIRAD/supagro), 34988, Montferrier Sur Lez, France

${ }^{\mathrm{d}}$ Key Laboratory of Tropical Forest Ecology, Xishuangbanna Tropical Botanical Garden, Chinese Academy of Sciences, Menglun, Mengla, Yunnan, 666303, China

${ }^{*}$ Corresponding author. E-mail address: larissagelias@yahoo.com (L.G. Elias).

Keywords: Ficus, Functional morphology, Parasitic Hymenoptera, Parasitoid, Plant-insect interaction 


\section{Abstract}

The high adaptive success of parasitic Hymenoptera might be related to the use of different oviposition sites, allowing niche partitioning among co-occurring species resulting in life history specialization and diversification. In this scenario, evolutionary changes in life history and resources for oviposition can be associated with changes in ovipositor structure, allowing exploitation of different substrates for oviposition. We used a formal phylogenetic framework to investigate the evolution of ovipositor morphology and life history in agaonid wasps. We sampled 24 species with different life histories belonging to all main clades of Agaonidae including representatives of all described genera of non-pollinating fig wasps (NPFW). Our results show an overall correlation between ovipositor morphology and life history in agaonid fig wasps. Ovipositor morphologies seem to be related to constraints imposed by features of the oviposition sites since ovipositor morphology has experienced convergent evolution at least four times in Sycophaginae (Agaonidae) according to the resource used. Nongalling species have more distantly spaced teeth with uneven spacing, as opposed to the observed morphology of galling species. Our results suggest that the ancestral condition for ovipositor morphology was most likely the presence of one or two apical teeth. Regarding life history, ovary galling species that oviposit in receptive figs possibly represent the ancestral condition. Different ovipositor characteristics allow exploitation of new niches and may be related to resource partitioning and species co-existence in the fig-fig wasp system.

\section{Introduction}

Oviposition is a crucial step for the reproductive success of insects because finding and assessing suitable oviposition sites play a decisive role in the successful development of offspring. Within this context, oviposition behaviour and ovipositor structure have an important adaptive role, allowing exploitation of diverse oviposition sites (Gauld and Bolton, 1988). Among Hymenoptera, there is a wide diversity of resources used for oviposition, which is related to the highly diversified life history strategies of the group, including galling, endo- and ectoparasitoid habits (Sharkey, 2007; Heraty et al., 2011). The high adaptive success of parasitic Hymenoptera might be related to exploitation of different substrates for oviposition, allowing niche partitioning among co-occurring species and leading to specialization and diversification (Pellmyr et al., 1996; Ronquist, 1999; Devictor et al., 2010). In this scenario, evolutionary changes in life history and resource use can be associated with changes in ovipositor structure, facilitating the exploitation of different substrates for oviposition (Quicke et al., 1994, 1999; Le Ralec et al., 1996; Brajković et al., 1999; Vilhelmsen, 2000; Belshaw et al., 2003; Sharkey, 2007; Ghara et al., 2011; Kawakita and Kato, 2016).

Ovipositor penetration in the substrate involves sliding movements of the two pairs of gonapophyses derived from the 8th and 9th abdominal segments. These structures form the ovipositor and are linked by a tongue and groove mechanism called olistheter, which allows the parts to slide in relation to one another (Quicke et al., 1995, 1999). Teeth and notches on the tip of gonapophyses grip the substrate, anchoring the ovipositor by its distal extremity. Then, the reciprocal movement allows ovipositor insertion into the substrate, as one of the halves grips 
the substrate while the other is pushed inside (Quicke et al., 1995; Vincent and King, 1996; oring et al., 2009). The structural and mechanical complexity of ovipositors thus allows movement and precise egg deposition in different substrates (Quicke et al., 1999). However, the understanding of the paths leading to this functional diversity is not trivial, because different characters and strategies are highly conserved in some groups whereas they might have convergently evolved to a specific niche in others (Le Ralec, 1991).

Agaonid wasps associated with Ficus Tourn ex Linn (i.e., fig wasps) represent a model group for investigating such functional diversity regarding ovipositors in an evolutionary framework. The family represents a monophyletic group of Chalcidoidea (Heraty et al., 2013), which is strictly associated with Ficus plants, using Ficus inflorescences (figs) as their exclusive oviposition site. In the context of Apocrita phylogeny, Chalcidoidea is placed as sister group of Diaprioidea (Peters et al., 2017). Fig wasps are distributed worldwide and have a wide diversity of life histories and oviposition strategies (Cook and Rasplus, 2003; Cruaud et al., 2011a; Elias et al., 2012). They usually lay their eggs in the ovaries of pistillate flowers or in the fig receptacle, inducing a gall (Galil and Eisikowitch, 1968). Some of them also pollinate pistillate flowers, establishing an obligate mutualistic relationship with Ficus. Pollinating fig wasps (Agaonidae: Agaoninae, Kradibiinae, Tetrapusiinae) enter the inflorescence to oviposit and pollinate Ficus flowers. Other agaonid fig wasps (Agaonidae: Sycophaginae) generally do not enter figs and do not perform pollination, being called "nonpollinating fig wasps" (NPFW henceforth) (Weiblen, 2002). In this case, ovipositors must move inside the figs until they reach an adequate oviposition site (Ghara et al., 2011; Elias et al., 2012). These movements involve steering and bending (Kundanati and Gundiah, 2014), as described for braconid parasitoids of twig-boring larvae (Quicke et al., 1995, 1999). Steering mechanisms allow these species to reach the host in a concealed environment and to deposit the egg in a precise location.

Physical characteristics vary along the ontogenetic development of the fig and represent different constraints for oviposition by wasps. At the beginning of development, figs are small and flowers are still immature within them. Some NPFW species deposit their eggs and induce galls in the fig receptacle (Bronstein, 1999; Ghara et al., 2014) (i.e., receptacle gallers), which mainly consists of parenchymatous cells (Verkerke, 1986, 1987). Egg deposition by these species does not occur at a very precise location and consequently ovipositor manoeuvrability is possibly less important in such a homogeneous substrate. Therefore, it is expected that ovipositor teeth are not required for thorough manoeuvering.

Later during fig development, all pollinating fig wasps and some NPFW species use ovaries of pistillate flowers as their oviposition sites, inducing galls (i.e., ovary gallers). They usually insert their ovipositors through the flower stigma, as is the case for some NPFW that oviposit from outside (Grandi, 1929; Galil and Eisikowitch, 1969; Elias et al., 2012) and lay their eggs at a very precise location - between the nucellus and inner integument or inside the embryo sac, depending on the species (Grandi, 1966; Galil et al., 1970; Verkerke, 1989; Elias et al., 2012; Jansen-González et al., 2012). Pollinating wasps enter the fig and have direct access to the stigma surfaces, where the ovipositor is inserted. At least some ovary gallers that oviposit 
externally are subject to additional bending movements in order to insert their ovipositors through flower stigmas, with manoeuvrability and movement accuracy being even more crucial for these species (Elias et al., 2012). Thus, ovipositor teeth are expected to play a role in the oviposition process of externally ovipositing gallers, ensuring accuracy of movement. As fig tissues are rather homogeneous in texture at the stage when the ovary gallers deposit their eggs, the morphology of ovipositor teeth is expected to be adapted to this type of substrate (Ghara et al., 2011).

After oviposition by galling species, fig flowers undergo abrupt modifications such as cell hypertrophy and hyperplasia, altering the environment inside the fig (Jansen-González et al., 2012, 2014). Cleptoparasite and parasitoid fig wasps oviposit in already induced galls, so that their larvae feed on vegetal tissue or directly on the galler larvae, respectively (Joseph, 1958; Tzeng et al., 2008). At this stage, the internal structure of the fig is completely modified, with enlarged, thickwalled galls filling almost completely the fig interior. To deposit the eggs, the ovipositor has to thrust into tissues that are heterogeneous in texture, from swollen cells and meristematic tissue inside galled flower ovaries to the thickened gall walls, which pose different mechanic challenges regarding anchoring and penetration. Therefore, a variable ovipositor tooth system is expected, permitting appropriate grip in different-textured tissues.

Ovipositor tooth characters have been investigated in depth in parasitic wasps within a mechanistic framework (e.g., Belshaw et al., 2003 in Ichneumonoidea, and Ghara et al., 2011 in fig wasps). Ghara et al. (2011) demonstrated that the ovipositor microstructure of NPFW species associated with F. racemosa matches resource use, i.e. the ovipositor of parasitoid species has a larger number of sensilla and ovipositor teeth and the extent of sclerotisation of the ovipositor tip correlates with the force required to penetrate the fig wall. However, studies investigating changes in life history and oviposition sites in relation to changes in ovipositor morphology in an explicitly evolutionary framework are largely missing. Within this context, we studied 24 agaonid species with different life histories (e.g., galling and nongalling species), which, therefore, use different resources for oviposition. Study species represent all main clades of Agaonidae, including representatives of four pollinating species and all described genera of NPFW species. In addition to acquisition of data for various species, recent improved phylogenetic understanding of NPFW taxa (e.g., Cruaud et al., 2011a, 2011b) has permitted an explicit comparative analysis. We used a formal phylogenetic framework 1) to investigate the correlation between the evolution of overall ovipositor morphology and life history in agaonid wasps, and 2) to identify functional traits related to ovipositor teeth and to estimate how these traits evolved in Agaonidae. We hypothesised that fig wasps with different life histories and, therefore, using different resources for oviposition, would exhibit differences regarding ovipositor structure. We adopted a comparative approach aimed at understanding the evolution of different strategies related to the solution of a common problem regarding resource use. 


\section{Methods}

\subsection{Study species}

We sampled 24 species with different life histories and therefore ovipositing in different substrates throughout fig development in order to maximize the ecological and phylogenetic diversity under consideration. The present study species belong to all main clades of Agaonidae including representatives of all described genera of NPFW (according to the phylogenetic hypotheses of Cruaud et al., 2011a, 2011b) in addition to four genera of pollinating wasps. All study species' life histories are known from the literature or from personal observation by the authors (Galil et al., 1970; Elias et al., 2008, 2012; Peng et al., 2005; Wang and Zheng, 2008; Cruaud et al., 2011a; Farache et al., 2013). We included 10 Neotropical species (associated with six Ficus hosts), 12 Indo-Australasian species (associated with 10 Ficus hosts), and two Afrotropical species (associated with two Ficus hosts) (Table 1). Vouchers are deposited at CBGP (INRA), Montferrier-sur-Lez, France.

\subsection{Ovipositor characters}

Observation and measurements were made from fresh material, as well as from $100 \%$ ethanol-preserved material and dry specimens. Body length was estimated by adding the measures of head length, mesosome length and metasome length. Measurements were made on 10 to 20 individuals of each species under a Leica MZ 16 stereomicroscope (40X magnification). Ovipositors from two to five individuals of each species were dissected, dehydrated in alcohol series when necessary, gold coated for $280 \mathrm{~s}$ and examined with a Zeiss EV050 Scanning Electron Microscope (SEM).

Table 1

Study species, taxonomic and ecological information. $\mathrm{NG}=$ Non-galler; $\mathrm{OG}=\mathrm{Ovary}$ galler; Poll $=$ Pollinator; RG = Receptacle galler. * indicates non-pollinating species that enter syconia.

\begin{tabular}{|c|c|c|c|c|c|}
\hline $\begin{array}{l}\text { Life } \\
\text { history }\end{array}$ & Fig wasp species & $\begin{array}{l}\text { Fig wasp } \\
\text { subfamily }\end{array}$ & $\begin{array}{l}\text { Host Ficus species } \\
\text { (Ficus section) }\end{array}$ & Country & Specimen \\
\hline Poll & Ceratosolen $\mathrm{sp}$ & Kradibiinae & F. hispida (Sycocarpus) & Laos & 5372_0199 \\
\hline Poll & Pegoscapus sp & Agaoninae & $\begin{array}{l}\text { F. citrifolia } \\
\text { (Americanae) }\end{array}$ & Brazil & 2672_0195 \\
\hline Poll & Platyscapa sp & Agaoninae & $\begin{array}{l}\text { F. concinna } \\
\text { (Urostigma) }\end{array}$ & China & 1660_0101 \\
\hline Poll & Tetrapus sp & Tetrapusinae & $\begin{array}{l}\text { F. obtusiuscula } \\
\text { (Pharmacosycea) }\end{array}$ & Brazil & 2685_0101 \\
\hline OG & $\begin{array}{l}\text { Idarnes sp.3 } \\
\text { (flavicollis group) }\end{array}$ & Sycophaginae & F. eximia (Americanae) & Brazil & 2565_0295 \\
\hline OG & Idarnes flavicollis & Sycophaginae & $\begin{array}{l}\text { F. obtusifolia } \\
\text { (Americanae) }\end{array}$ & Brazil & 2579_0295 \\
\hline
\end{tabular}




\begin{tabular}{|c|c|c|c|c|c|}
\hline OG & Sycophaga fusca & Sycophaginae & $\begin{array}{l}\text { F. racemosa } \\
\text { (Sycomorus) }\end{array}$ & India & 1223_0203 \\
\hline OG & Sycophaga sp & Sycophaginae & $\begin{array}{l}\text { F. auriculata } \\
\text { (Sycomorus) }\end{array}$ & China & 0825_1294 \\
\hline OG* & Sycophaga silvestrii* & Sycophaginae & F. sur (Sycomorus) & Senegal & 2451_0295 \\
\hline $\mathrm{OG}^{*}$ & $\begin{array}{l}\text { Sycophaga } \\
\text { sycomori* }\end{array}$ & Sycophaginae & $\begin{array}{l}\text { F. mucuso } \\
\text { (Sycomorus) }\end{array}$ & Cameroun & 1932_0302 \\
\hline OG & Sycophaga testacea & Sycophaginae & $\begin{array}{l}\text { F. racemosa } \\
\text { (Sycomorus) }\end{array}$ & India & 1223_0103 \\
\hline RG & Anidarnes dissidens & Sycophaginae & $\begin{array}{l}\text { F. obtusifolia } \\
\text { (Americanae) }\end{array}$ & Brazil & 2586_0201 \\
\hline RG & Anidarnes rugosus & Sycophaginae & $\begin{array}{l}\text { F. crocata } \\
\text { (Americanae) }\end{array}$ & Brazil & 2578_0201 \\
\hline RG & Conidarnes sp. & Sycophaginae & $\begin{array}{l}\text { F. sumatrana } \\
\text { (Urostigma) }\end{array}$ & Indonesia & 2085_0201 \\
\hline RG & $\begin{array}{l}\text { Idarnes sp.7 (incertus } \\
\text { group) }\end{array}$ & Sycophaginae & $\begin{array}{l}\text { F. citrifolia } \\
\text { (Americanae) }\end{array}$ & Brazil & 2136_0202 \\
\hline RG & Pseudidarnes cooki & Sycophaginae & $\begin{array}{l}\text { F. obliqua } \\
\text { (Malvanthera) }\end{array}$ & Australia & 2558_0101 \\
\hline RG & Pseudidarnes sp. & Sycophaginae & F. baola (Malvanthera) & $\begin{array}{l}\text { Solomon } \\
\text { Islands }\end{array}$ & 2523_0201 \\
\hline RG & $\begin{array}{l}\text { Pseudidarnes } \\
\text { minerva }\end{array}$ & Sycophaginae & $\begin{array}{l}\text { F. rubiginosa } \\
\text { (Malvanthera) }\end{array}$ & Australia & 1418_2801 \\
\hline NG & Eukoebelea sp. & Sycophaginae & Ficus sp. (Malvanthera) & Australia & $1418 \_3005$ \\
\hline NG & Idarnes punctata & Sycophaginae & F. eximia (Americanae) & Brazil & 2569_0295 \\
\hline NG & Idarnes sp.1 & Sycophaginae & $\begin{array}{l}\text { F. citrifolia } \\
\text { (Americanae) }\end{array}$ & Brazil & 2559_0295 \\
\hline NG & Idarnes sp.9 & Sycophaginae & $\begin{array}{l}\text { F. obtusifolia } \\
\text { (Americanae) }\end{array}$ & Brazil & 2580_0201 \\
\hline NG & Sycophaga agraensis & Sycophaginae & $\begin{array}{l}\text { F. racemosa } \\
\text { (Sycomorus) }\end{array}$ & India & 1360_0503 \\
\hline NG & $\begin{array}{l}\text { Sycophaga } \\
\text { spinitarsus }\end{array}$ & Sycophaginae & $\begin{array}{l}\text { F. variegata } \\
\text { (Sycomorus) }\end{array}$ & Australia & 1423_0201 \\
\hline
\end{tabular}

Based on a functional approach, we used characters related to ovipositor teeth for their potential role in drilling and/or anchoring the ovipositor, allowing its movement through the substrate (Le Ralec, 1991; Le Ralec et al., 1996; Quicke et al., 1999; Belshaw et al., 2003; Vilhelmsen and Turrisi, 2011) (Table 2 and Figure S1).

We did not include ovipositor length or ovipositor diameter in the analysis since these characters are correlated with fig size (Zhen et al., 2005; Tzeng et al., 2014). We used absolute 
rather than relative measurements because no correlation between ovipositor traits and wasp size was detected (Supplementary material - Figure S5).

2.3. DNA sequencing, sequence alignment and phylogenetic analyses

The molecular protocols were applied as described by Cruaud et al. (2011a) and specimen sampling locations, hosts, and GenBank sequences are presented in Supplementary material (Table S1).

In order to obtain a more robust phylogenetic inference and to avoid tree-search artifacts caused by subsampling and long-branch attraction, the species analysed in this study were combined with the ingroup species used in the most comprehensive dataset for Sycophaginae to date (Cruaud et al., 2011b). A time-calibrated tree was obtained using BEAST v 2.4.2 (Drummond and Rambaut, 2007) (Figure S6) and subsequently pruned in order to keep only the studied taxa (Figure S7).

Table 2

Ovipositor traits coded into continuous characters for this study.

\begin{tabular}{|c|c|}
\hline Character & Formula \\
\hline $\begin{array}{l}\text { 1. Number of teeth on } \\
\text { gonapophysis IX }\end{array}$ & - \\
\hline $\begin{array}{l}\text { 2. Mean tooth height } \\
(\mathrm{mm})\end{array}$ & $\begin{array}{l}\Sigma \text { tooth height/tooth } \\
\text { number }\end{array}$ \\
\hline $\begin{array}{l}\text { 3. Coefficient of variation } \\
\text { of tooth height }\end{array}$ & $\begin{array}{l}\text { SD of tooth } \\
\text { height/mean tooth } \\
\text { height }\end{array}$ \\
\hline $\begin{array}{l}\text { 4. Mean distance between } \\
\text { teeth }(\mathrm{mm})\end{array}$ & $\begin{array}{l}\Sigma \text { distance between } \\
\text { teeth/(tooth number)- } \\
1\end{array}$ \\
\hline $\begin{array}{l}\text { 5. Coefficient of variation } \\
\text { of distance between } \\
\text { teeth }\end{array}$ & $\begin{array}{l}\text { SD of distance } \\
\text { between teeth/mean } \\
\text { distance between } \\
\text { teeth }\end{array}$ \\
\hline $\begin{array}{l}\text { 6. Relative ovipositor } \\
\text { length bearing teeth } \\
(\mathrm{mm})\end{array}$ & $\begin{array}{l}\text { Portion bearing } \\
\text { teeth/total ovipositor } \\
\text { length }\end{array}$ \\
\hline
\end{tabular}

Phylogenetic analyses and molecular dating are described in detail in the Supplementary material. 


\subsection{Correlation between ovipositor traits and life history}

In order to determine which ovipositor traits are related to life history, the relationship between each morphological character (Table 2$)$ and life history $(0=$ galler or $1=$ non-galler $)$ was analysed with a phylogenetic generalised linear model for binomial response (Ives and Garland, 2010) using the "phylolm" package (Ho and Ané, 2014), as implemented in R environment (R Development Core Team, 2015).

As recommended by Revell (2010), the phylogenetic signal is estimated simultaneously with the regression coefficients. This measure of phylogenetic signal is associated with $\alpha$, that gives the change rates among trait values. A value of a $(-\log \alpha)$ greater than one represents a strong phylogenetic signal, whereas values of -4.0 or less indicate a low phylogenetic signal (Ives and Garland, 2010).

We used a model comparison approach (Burnham and Anderson, 2002) based on Akaike Information Criterion (AIC) to rank competing models. We calculated the difference between the AIC of each model and the lowest $\mathrm{AIC}$ value $\left(\triangle \mathrm{AIC} \mathrm{C}_{\mathrm{i}}=\mathrm{AIC}_{\mathrm{i}}-\mathrm{AIC}_{\min }\right)$; therefore, the best model had a $\triangle \mathrm{AIC}=0$. We estimated the relative weight of each model (wAIC), which represents the likelihood of a given model to be the best one among a set of concurrent models (Johnson and Omland, 2004). Models with $\triangle \mathrm{AIC} \leq 2$ and wAIC $\geq 0.10$ were considered equally plausible to explain the observed data (Burnham and Anderson, 2002; Johnson and Omland, 2004). As a baseline for comparison, we included a null model (i.e., dependent variable constant), which refers to the absence of effect.

Because morphological characters (Table 2) reflect ovipositor tooth morphology, they do not apply to species that lack ovipositor teeth. Therefore, only species that bear teeth in their ovipositors were included in this analysis (16 species).

\subsection{Evolution of ovipositor traits}

In order to better understand how morphological characters (Table 2) evolved in Agaonidae, we performed ancestral state

Table 3

Ovipositor and life history traits coded into discrete (i.e., categorical) characters. NA: not applicable.

\begin{tabular}{lll}
\hline Character & Binary coding & Multistate coding \\
\hline $\begin{array}{c}\text { Ovipositor } \\
\text { morphology }\end{array}$ & NA & $\begin{array}{l}0=\text { Multiple } \\
\text { uniform teeth } \\
1=\text { Multiple } \\
\text { serrated teeth } \\
2=\text { No teth } \\
3=\text { One or two } \\
\text { apical teeth } \\
0=\text { Pollinating-ovary galler (receptive } \\
\text { flowers) }\end{array}$ \\
Life history $\quad 0=$ Galler & 1 = Non-pollinating-ovary galler (receptive flowers) \\
2 $=$ Receptacle galler (pre-receptive flowers) & 1 = Non-galler3 = Non-galler (galled flowers)
\end{tabular}


reconstruction analysis. We used a likelihood framework implemented on the $\mathrm{R}$ package phytools (Revell, 2012). For each character, values were colour-coded, so that the variation in colour seen in the reconstruction reflected variation in character values.

Furthermore, to investigate how both general ovipositor morphology and life history change throughout the evolutionary history of Agaonidae, ancestral states were also estimated. In this case, characters were coded as multistate to provide summarised information. Multistate codings for overall ovipositor morphology and life history are detailed in Table 3. Analyses were performed in R environment with the package phytools (Revell, 2012), using a stochastic reconstruction that allowed the calculation of a Bayesian posterior probability distribution. The results of 1000 stochastic character maps for each trait were used to estimate probabilities at each node (Revell, 2013). States for each character were colour-coded and probabilities of each state at nodes were represented by pie charts.

\section{Results}

\subsection{Morphological and phylogenetic data}

Overall ovipositor morphology and tooth measurements, as well as the tree representing the phylogenetic relationships and divergence times among the 24 study species were used as the framework for all comparative studies and are shown in the Supplementary material (Figures S2-S4, Figure S7 and Table S2).

Eukoebelea was recovered as the sister group for all other Sycophaginae. Idarnes and Sycophaga were recovered as monophyletic groups and each Idarnes species group was also recovered as monophyletic, with the carme species group being sister to the flavicollis + incerta species groups. Pseudidarnes + Anidarnes + Conidarnes were also monophyletic, in agreement with Cruaud et al. (2011a, 2011b).

All receptacle-galling species lack teeth on their ovipositors, regardless of the clade they belong to (Idarnes sp.7 (incertus group) is sister to a clade of tooth-bearing Idarnes). Even though vestigial teeth are present in the females of this species (Figure S2), they are not functional. The ovipositors of Agaonidae pollinating species bear one or two apical teeth. On the other hand, ovary-galling NPFW have multiple teeth in their ovipositors. Idarnes galling species bear fewer and shorter teeth than Sycophaga galling species (5-6 vs. 7-11, respectively, Table S2). However, internally ovipositing Sycophaga (Sycophaga sycomori and Sycophaga silvestrii) seem to have reduced ovipositor teeth which were the shortest among the study species. The non-galling NPFW also have multiple teeth in their ovipositors, Idarnes and Eukoebelea species have irregular serrated teeth, while non-galling Sycophaga have uniform teeth similar to those of the non-pollinating galling species. 
Table 4 Models tested to predict fig wasp life history ( 0 - galler, $1-$ non-galler). Models with $\triangle \mathrm{AIC}<2$ and wAIC $>0.1$ were considered equally plausible. wAIC $=$ model weight, $\mathrm{a}=$ phylogenetic signal estimated for the regression, na $=$ not applicable.

\begin{tabular}{|c|c|c|c|c|c|}
\hline $\begin{array}{l}\text { Model } \\
\text { Predictor }\end{array}$ & Slope & AIC & $\Delta \mathrm{AIC}$ & wAIC & $\mathrm{a}$ \\
\hline $\begin{array}{l}\text { Coefficient of } \\
\text { variation of } \\
\text { distance } \\
\text { between } \\
\text { teeth }\end{array}$ & + & 15.52 & 0 & 0.508 & 0.70 \\
\hline $\begin{array}{l}\text { Mean distance } \\
\text { between teeth }\end{array}$ & + & 16.02 & 0.5 & 0.395 & 1.10 \\
\hline Null model & na & 22.33 & 6.81 & 0.017 & 1.40 \\
\hline $\begin{array}{l}\text { Number of } \\
\text { teeth }\end{array}$ & + & 23.98 & 8.46 & 0.007 & 1.40 \\
\hline $\begin{array}{l}\text { Coefficient of } \\
\text { variation of } \\
\text { tooth height }\end{array}$ & + & 24.29 & 8.77 & 0.006 & 1.52 \\
\hline $\begin{array}{l}\text { Relative } \\
\text { ovipositor } \\
\text { length bearing } \\
\text { teeth }\end{array}$ & - & 24.38 & 8.86 & 0.006 & 1.40 \\
\hline $\begin{array}{l}\text { Mean tooth } \\
\text { height }\end{array}$ & + & 24.76 & 9.24 & 0.005 & 1.40 \\
\hline
\end{tabular}

3.2. Correlation between ovipositor traits and life history

The coefficient of variation of distance between teeth and the mean distance between teeth were equally plausible to predict the life history of fig wasps $\left(\triangle \mathrm{AIC} \leq 0.5, \sum \mathrm{wAIC}=0.903\right)$, i.e. species with more widely spaced teeth and more uneven tooth spacing are more likely to be non-gallers. All other tested models contributed little to the explanation of fig wasp life history. Indeed, most of them were less plausible than the null model (Table 4). Most a values were higher than 1.0, indicating a phylogenetic signal in the response variable (life history). Our approach using a general phylogenetic linear model was therefore suitable.

\subsection{Evolution of ovipositor traits}

We presented ancestral character state reconstructions only for the ovipositor traits significantly correlated with life history $(\triangle \mathrm{AIC}<2$ and wAIC $>0.1$ ) (Fig. 2). Reconstructions for all study characters are presented in Supplementary material (Figures S8-S9).

In Sycophaga, both mean and coefficient of variation of distance between teeth are higher in the non-galling species (violet to black colours in Fig. 2). In Idarnes, more spaced and uneven 
spacing among teeth also occurred in non-galling species (dark blue to black colours in the nongalling clade Idarnes sp.1 + Idarnes sp.9 + Idarnes punctata, Fig. 2).

The ancestral condition of the overall ovipositor morphology of Agaonidae was probably uniform teeth (67\% posterior probability) or one-two apical teeth ( $32 \%$ posterior probability). Regarding life history, pollinating or non-pollinating ovary gallers were probably the ancestral state (70\% and 28\%, respectively) (Fig. 1). Loss of ovipositor teeth occurred independently at least twice in Sycophaginae lineages in which wasps are receptacle gallers. However, this number may have been underestimated since some Sycophaga that gall fig receptacles (Cruaud et al., 2011a) were not included in our analyses. Non-galling life history evolved at least three times in Sycophaginae, i.e., Sycophaga spinitarsus + Sycophaga agraensis clade, Eukoebelea, and Idarnes carme species group clade (Fig. 1).

Shifts in life history and resource use were correlated with shifts in overall ovipositor structure in the Idarnes clade. Within Idarnes, all shifts in life history were associated with changes in overall ovipositor morphology. Ovipositors exhibit multiple uniform teeth in ovarygalling species, whereas non-galling species have multiple serrated teeth. Species that induce galls in the receptacle lack teeth on their ovipositors. On the other hand, within Sycophaga, the shift from ovary-galling to non-galling life history in the clade Sycophaga agraensis + Sycophaga spinitarsus was not followed by changes in overall ovipositor morphology, which maintained the ancestral condition of uniform teeth. 


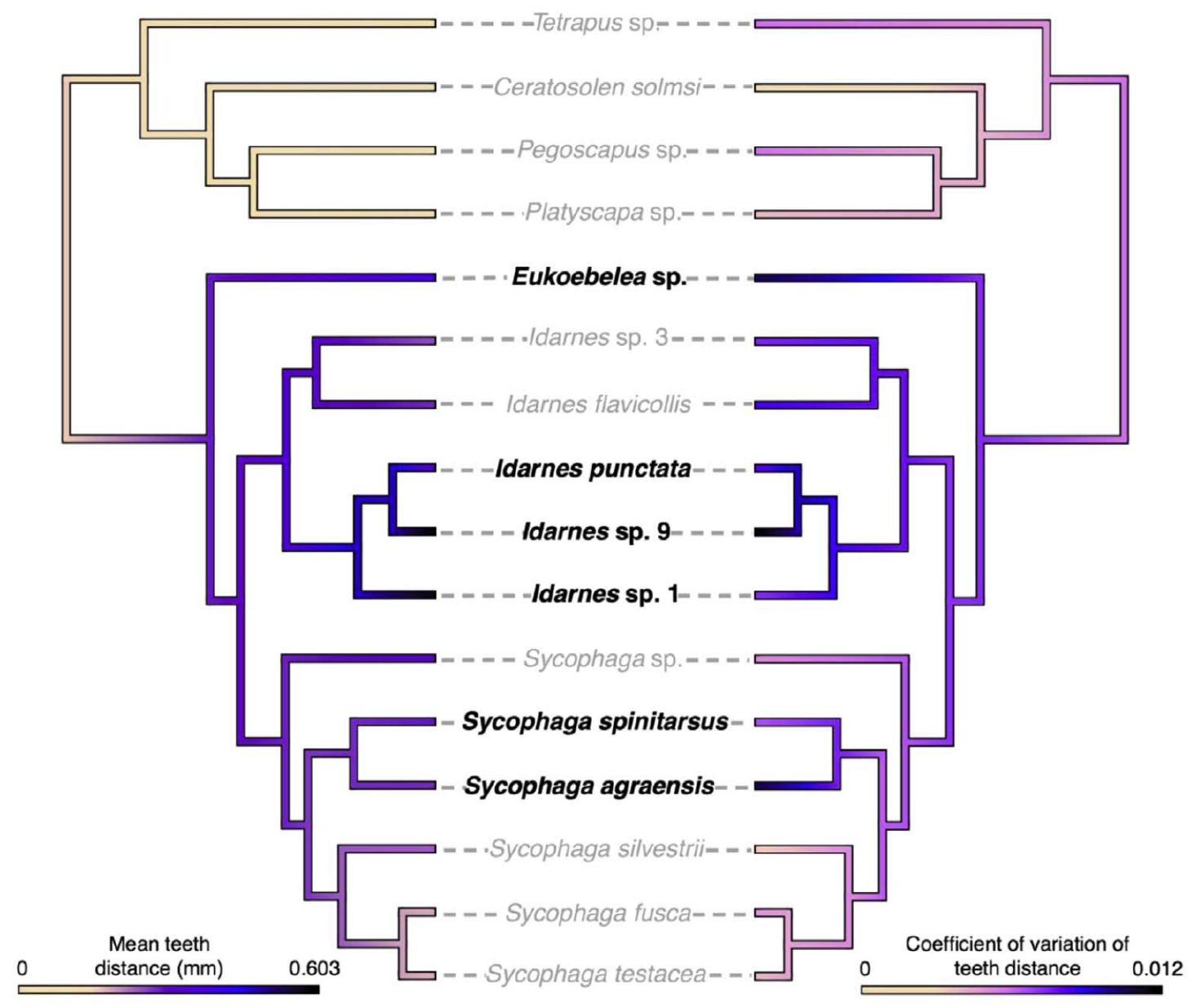

Fig. 1. Patterns of evolution of mean distance between teeth (left) and coefficient of variation of distance between teeth (right) in the ovipositors of fig wasp species (Hymenoptera: Agaonidae). Colour shifts reflect changes in these characters throughout evolution of the group. Scale bars at the bottom show correspondence of colours and values for each character. Reconstructions were performed under a likelihood framework. Species in grey correspond to galling life history, while species in black are non-gallers. Character mapping schemes were mirrored to allow the simultaneous appreciation of a pair of characters being reconstructed. 


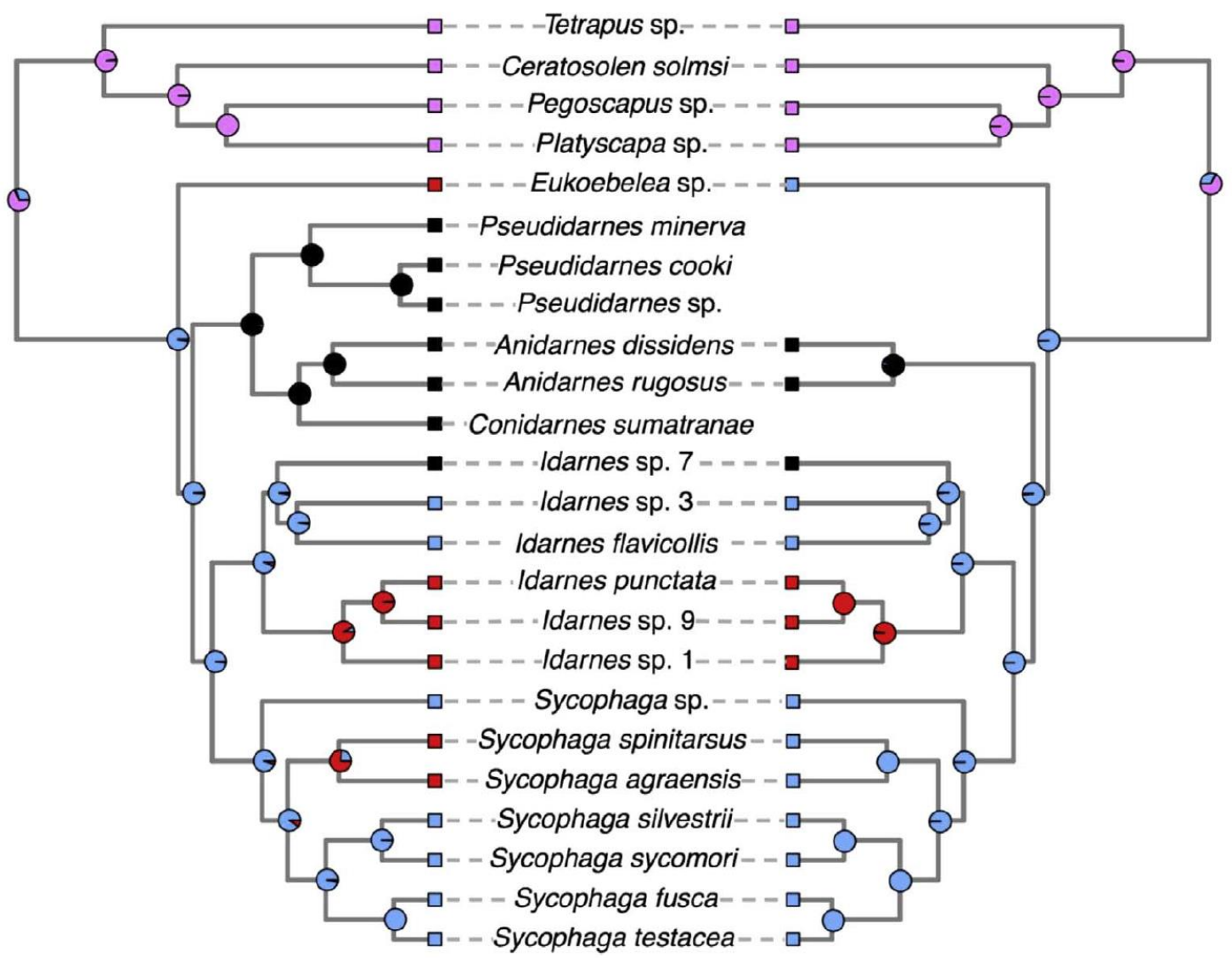

Fig. 2. Patterns of evolution of life history (left) and ovipositor morphology (right) in the studied fig wasp species (Hymenoptera: Agaonidae). Squares representing each terminal taxon are colour-coded according to life history on the left tree (pink = pollinating ovary gallers, blue $=$ non-pollinating ovary gallers, black $=$ receptacle gallers, and red $=$ non-gallers $)$ and according to overall ovipositor morphology on the right tree (pink = one or two apical teeth, blue $=$ multiple uniform teeth, black $=$ no teeth, and red $=$ multiple serrated teeth). Pie charts at each node represent probabilities of ancestral states using Bayesian posterior probabilities. Absent taxa on the right tree indicate missing data. (For interpretation of the references to colour in this figure legend, the reader is referred to the web version of this article.)

\section{Discussion}

Our results showed that overall ovipositor morphology is generally correlated with life history in agaonid fig wasps. This correlation seems to be driven by the characteristics of the substrate used for oviposition (Kawakita and Kato, 2016). Ovipositor morphologies seem to be related to constraints imposed by features of the oviposition sites, since ovipositor morphology has experienced convergent evolution at least four times in Sycophaginae according to the resource used (i.e., receptacle, flower ovary, induced galls; Fig. 2). The use of the fig receptacle 
is associated with absence of ovipositor teeth. Among ovary gallers, pollinating wasps have one or two teeth in the distal extremity of their ovipositors and galling NPFW species have multiple homogeneously sized and spaced teeth. On the other hand, most non-galling fig wasps have multiple teeth with heterogeneous size and spacing.

Non-pollinating ovary gallers that enter the fig receptacle to lay eggs (i.e., Sycophaga sycomori and S. silvestrii), however, do not completely follow this pattern, but a more detailed analysis reveals morphological convergences that support the morphology-life history correlation. Both S. sycomori and S. silvestrii have multiple teeth like their congeneric species that oviposit externally. Nonetheless, the teeth of these species are less developed, being 2-3 times shorter than those of the externally ovipositing Sycophaga (Figure S3 and Table S2). These less developed teeth may suggest that manoeuvrability is not an issue for internal galling species. Indeed, pollinators (Agaonidae) oviposit internally and have one or two teeth in their ovipositors, as ovipositor insertion occurs along the vascular bundle of receptive flowers, which is used as a guide (Verkerke, 1987). On the other hand, Sycophaga wasps evolved strategies differing from those of pollinators and have a different mode of ovipositor insertion in the flower and location of egg deposition (Galil et al., 1970; data on Sycophaga sycomori). In both cases, there seems to be limited pressure for selecting a complex tooth system in ovipositors, supporting the idea of a potentially simpler ovipositor in terms of capacity of movements and/or anchoring.

The scenario is different for externally ovipositing ovary gallers. Their ovipositors reach the interior of the fig and have to bridge gaps between flowers until they are inserted (Elias et al., 2012; data on Idarnes sp.3). Tooth morphology may be involved in ovipositor movement inside the fig, through flowers that are used as anchoring points until the exact oviposition site is reached (Vincent and King, 1996). These wasps also insert their ovipositors through the stigma of mature pistillate flowers, as pollinators do (Elias et al., 2012; data on Idarnes sp.3). Therefore, oviposition in young flower ovaries involves precise ovipositor insertion, which seems to be related to the uniform ovipositor structure found in galling Sycophaginae wasps.

The association between life history and ovipositor traits suggested by descriptive data was confirmed by phylogenetic regression analysis. Mean distance between teeth and the coefficient of variation of distance between teeth showed that non-galling species have more spaced teeth, with uneven spacing, as opposed to what was observed in galling species. The other variables analysed (tooth number, mean tooth height, coefficient of variation of tooth height, and relative ovipositor length that bears teeth) did not show a significant correlation, possibly because they are not related to life history or because they have no biological meaning alone. Our results suggest that maneuverability relies on tooth spacing and on the unevenness of tooth spacing. Teeth that are closer together possibly permit fine movement, while teeth that are further apart would permit the use of substrates with different textures and structures.

Regarding the evolution of life histories and ovipositor traits within Agaonidae, our results suggest that the ancestral condition for ovipositor morphology was most likely the presence of one to two apical teeth. Regarding life history, ovary galling species that oviposit in receptive 
figs possibly represent the ancestral state. It is important to note that the results of both independent analyses were biologically compatible, increasing our confidence in these data.

Receptacle galling life history arose at least two times (our sampling did not include receptacle gallers within Sycophaga) and was always correlated to the loss of ovipositor teeth. In the clade Pseudidarnes + Anidarnes + Conidarnes, ovipositor teeth were completely lost. However, Idarnes sp.7 (incertus group) shows some vestigial teeth that could be related to a recent loss, associated with a recent shift to receptacle galler habit. Loss of ovipositor teeth also occurred in other fig-related Chalcidoidea that are receptacle gallers (L.G. Elias, unpublished data on Epichrysomallinae and Otitesellinae). This relationship is also observed in other Parasitica species that oviposit in shallow substrates or in exposed hosts and have fewer or no teeth. This is the case for Braconidae wasps that parasitise exposed hosts or hosts that live close to the surface (Brajković et al., 1999), sawflies that glue their eggs to the leaf surface (Weltz and Vilhelmsen, 2014) and Platygaster diplosisae (Platygasteridae) that parasitises hosts with a very thin egg envelope (Nacro and Nénon, 2009). Loss of ovipositor teeth in these groups supports the hypothesis that multiple teeth are related to drilling through the fig wall and to ovipositor movement inside figs.

Evolution of non-galling habit occurred three times independently in our reconstructions, but general ovipositor morphology did not undergo substantial modifications in Sycophaga agraensis + Sycophaga spinitarsus. These wasps have uniform teeth like other Sycophaginae, supporting our idea of versatility of this ovipositor morphology, which seems to be adapted to oviposition in different substrates (Ficus flowers or developed galls). Alternatively, in the Idarnes clade and in Eukoebelea, a different, serrated ovipositor structure evolved in correlation with the shift in life history, demonstrating different solutions to explore analogous substrates among fig wasp clades. In fact, serrated ovipositors occur in the majority of non-galling fig wasps (L.G. Elias, unpublished data on Sycoryctinae and other fig-associated Chalcidoidea). Moreover, oviposition in harder substrates is also usually correlated to serrated ovipositors in other parasitic Hymenoptera (Quicke et al., 1999).

Our results provide new data that contribute to the understanding of the origin and maintenance of the fig-fig wasp mutualism. The ancestral Agaonidae probably used flower ovaries as oviposition sites due to the high nutritional value of these structures. Flower ovaries are expensive resources because they are directly linked to the reproductive success of the plant. Nonetheless, the exchange of such valuable resource was maintained throughout the evolutionary history of the mutualism. Indeed, the Ficus-fig wasp association is exceptional among nursery mutualisms because it represents a stable relationship, with very few reversals (but see Compton et al., 1991; Peng et al., 2008). The use of other resources for oviposition (fig receptacle or galls) emerged later in the evolution of the group in what seems to be a case of adaptive radiation related to the occupancy of new niches (Schluter, 2000). Paradoxically, the greatest species diversification within Sycophaginae has occurred among non-galling wasps, probably due to their wider niche amplitudes (Elias et al., 2008). However, the evolution of this life history, as well as the receptacle galling life history, were conditional on the previous 
existence of mutualism, highlighting the role of mutualistic interactions as sources of biological diversification.

Our results show that, in most cases, ovipositor characteristics are related to the use of different resources as oviposition sites (Kawakita and Kato, 2016). Different ovipositor characteristics allow the exploitation of new niches and may be related to resource partitioning and species co-existence in the fig-fig wasp system. The evolutionary approach used in the present study unravelled how different life histories evolved in correlation with morphological traits in fig wasps and opens new perspectives for studies regarding other species involved in multitrophic interactions.

Funding

This work was supported by the Sao Paulo Research Foundation (FAPESP), grant numbers 2007/59059-3 and 2013/01918-1 (L.G. Elias); 2015/06430-2 (F.H.A. Farache); 2011/09477-9 (E.A.B.

Almeida); 2015/25417-7 (R.A.S. Pereira), and by the National Council for Scientific and Technological Development (CNPq) grant number 306078/2014-7).

Acknowledgements

We thank Liam J. Revell (University of Massachusetts) for advice about the use of phytools functions and Atsushi Kawakita (Kyoto University) for discussion of the correlation between ovipositor morphology and life history traits. We are also indebted to Anne Le Ralec (Agrocampus Ouest, Rennes) for valuable discussion of ovipositor morphology, to Huan Gang, Yang Pei and Wenjuan Ma (XTBG) for help with field work in Xishuangbanna Tropical Botanical Garden, and to Rodrigo Silva (FFCLRP - Universidade de São Paulo) and Laurent Soldati (CBGP, Institut National de la Recherche Agronomique) for help with Scanning Electron Microscopy. We thank Elettra Greene for the English revision.

Appendix A. Supplementary data related to this article can be found at http://dx.doi.org/10.1016/j.actao.2017.10.007.

\section{References}

Belshaw, R., Grafen, A., Quicke, D.L.J., 2003. Inferring life history from ovipositor morphology in parasitoid wasps using phylogenetic regression and discriminant analysis. Zool. J. Linn. Soc. 139, 213-228.

Boring, C.A., Sharkey, M.J., Nychka, J.A., 2009. Structure and functional morphology of the ovipositor of Homolobus truncator (Hymenoptera: Ichneumonoidea: Braconidae). J. Hymenopt. Res. 18, 1-24.

Brajković, M., Krunić, M., Tomanović, Ž., Stanisavljević, L.J., 1999. Morphological adaptations of the ovipositor of braconid wasps (Braconidae: Hymenoptera) associated to biological characteristics of their hosts. Acta entomol. Serb 4, 107-125. 
Bronstein, J.L., 1999. Natural history of Anidarnes bicolor (Hymenoptera: Agaonidae), a galler of the Florida strangler fig (Ficus aurea). Fla. Entomol. 82, 454-561.

Burnham, K.P., Anderson, D.R., 2002. Model Selection and Multimodel Inference: a Practical Information e Theoretic Approach. Springer-Verlag, New York.

Compton, S.G., Holton, K.C., Rashbrook, V.K., van Noort, S., Vincent, S.L., Ware, A.B., 1991. Studies of Ceratosolen galili, a non-pollinating agaonid fig wasp. Biotropica 23, 188-194.

Cook, J., Rasplus, J.Y., 2003. Mutualists with attitude: coevolving fig wasps and figs. Trends Ecol. Evol. 18, 241-248.

Cruaud, A., Jabbour-Zahab, R., Genson, G., Kjellberg, F., Kobmoo, N., van Noort, S., DaRong, Y., Yan-Qiong, P., Ubaidillah, R., Hanson, P.E., Santos-Mattos, O., Farache, F.H.A., Pereira, R.A.S., Kerdelhue, C., Rasplus, J.-Y., 2011a. Phylogeny and evolution of life-history strategies in the Sycophaginae non-pollinating fig wasps (Hymenoptera, Chalcidoidea). BMC Evol. Biol. 11.

Cruaud, A., Jabbour-Zahab, R., Genson, G., Couloux, A., Peng, Y.-Q., Rong, Y.D., Ubaidillah, R., Pereira, R.A.S., Kjellberg, F., van Noort, S., Kerdelhue, C., Rasplus, J.Y., 2011b. Out of Australia and back again: the world-wide historical biogeography of nonpollinating fig wasps (Hymenoptera: Sycophaginae). J. Biogeogr. 38, 209-225.

Devictor, V., Clavel, J., Julliard, R., Lavergne, S., Mouillot, D., Thuiller, W., Venail, P., Villéger, S., Mouquet, N., 2010. Defining and measuring ecological specialization. J. Appl. Ecol. 47, 15-25.

Drummond, A.J., Rambaut, A., 2007. BEAST: Bayesian evolutionary analysis by sampling trees. BMC Evol. Biol. 7, 214. http://dx.doi.org/10.1186/1471-2148-7-214.

Elias, L.G., Farache, F.H.A., do Ó, V.T., Pereira, R.A.S., 2008. Colonization sequence of nonpollinating fig wasps associated with Ficus citrifolia in Brazil. Symbiosis 45, 107-111.

Elias, L.G., Teixeira, S.P., Kjellberg, F., Pereira, R.A.S., 2012. Diversification in the use of resources by Idarnes species: bypassing functional constraints in the fig-fig wasp interaction. Biol. J. Linn. Soc. 106, 114-122.

Farache, F.H.A., Cruaud, A., Genson, G., Pereira, R.A.S., Rasplus, J.Y., 2013. Taxonomic revision and molecular phylogeny of the fig wasp genus Anidarnes (Hymenoptera:

Sycophaginae) Bouček, 1993. Syst. Entomol. 38, 14-34.

Galil, J., Eisikowitch, D., 1968. On the pollination ecology of Ficus sycomorus in east Africa. Ecology 49, 259-269.

Galil, J., Eisikowitch, D., 1969. Further studies on the pollination ecology of Ficus sycomorus L. (Hymenoptera, Chalcidoidea, Agaonidae). Tijdschr. Entomol. 112, 1-13.

Galil, J., Dulberger, R., Rosen, D., 1970. The effects of Sycophaga sycomori L. on the structure and development of the synconia in Ficus sycomorus L. New Phytol. 69, 103111.

Gauld, I.D., Bolton, B., 1988. The Hymenoptera. Oxford University Press, London.

Ghara, M., Kundanati, L., Borges, R.M., 2011. Nature's Swiss Army Knives: ovipositor structure mirrors ecology in a multitrophic fig wasp community. PLoS One 6 (8), e236. http://dx.doi.org/10.1371/journal.pone.0023642. 42. 
Ghara, M., Ranganathan, Y., Krishnan, A., Gowda, V., Borges, R.M., 2014. Divvying up an incubator: how parasitic and mutualistic fig wasps use space within their nursery microcosm. Arthropod-Plant Interact. 8, 191-203.

Grandi, G., 1929. Studio morfologico e biologico della Blastophaga psenes. Societa Tipografica Gia Compositori, Bologna, Italia.

Grandi, G., 1966. Istituzioni di Entomologia Generale. Calderini, Bologna, Italia.

Heraty, J., Ronquist, F., Carpenter, J.M., Hawks, D., Schulmeister, S., Dowling, A.P., Murray, D., Munro, J., Wheeler, W.C., Schiff, N., Sharkey, M., 2011. Evolution of the hymenopteran megaradiation. Mol. Phylogenet. Evol. 60, 73-88.

Heraty, J.M., Burks, R.A., Cruaud, A., Gibson, G.A.P., Liljeblad, J., Munro, J., Rasplus, J.Y., Delvare, G., Jansta, P., Gumovsky, A., Huber, J., Woolley, J.B., Krogmann, L., Heydon, S., Polaszek, A., Schmidt, S., Darling, D.C., Gates, M.W., Mottern, J., Murray, E., Molin, A.D., Triapitsyn, S., Baur, H., Pinto, J.D., van Noort, S., George, J., Yoder, M., 2013. A phylogenetic analysis of the megadiverse Chalcidoidea (Hymenoptera). Cladistics 29, 466-542.

Ho, L.S.T., Ané, C., 2014. A Linear-time algorithm for Gaussian and non-Gaussian trait evolution models. Syst. Biol. 63, 397-408.

Ives, A.R., Garland Jr., T., 2010. Phylogenetic logistic regression for binary dependent variables. Syst. Biol. 59, 9-26.

Jansen-González, S., Teixeira, S.P., Pereira, R.A.S., 2012. Mutualism from the inside: coordinated development of plant and insect in an active pollinating fig wasp.

Arthropod-Plant Interact. 6, 601-609.

Jansen-González, S., Teixeira, S.P., Kjellberg, F., Pereira, R.A.S., 2014. Same but different: larval development and gall-inducing process of a non-pollinating fig wasp compared to that of pollinating fig-wasps. Acta Oecol 57, 44-50.

Johnson, J.B., Omland, K.S., 2004. Model selection in ecology and evolution. Trends Ecol. Evol. 19, 101-108.

Joseph, K., 1958. Recherches sur les chalcidiens, Blastophaga psenes (L.) et Philotrypesis caricae (L.), du figuier (Ficus carica L.). Ann. Sci. Nat. Zool. Biol. Anim. 11e, 197-260.

Kawakita, A., Kato, M., 2016. Revision of the Japanese species of Epicephala Meyrick with descriptions of seven new species (Lepidoptera, Gracillariidae). ZooKeys 568, 87-118.

Kundanati, L., Gundiah, N., 2014. Biomechanics of substrate boring by fig wasps. J. Exp. Biol. 217, 1946-1954.

Le Ralec, A., 1991. Les hyménoptères parasitoïdes: adaptations de l'appareil reproducteur femelle. In: Morphologie et ultrastructure de l'ovaire, de l'œuf et de l'ovipositeur.

Université de Rennes I, France.

Le Ralec, A., Rabasse, J.M., Wajnberg, E., 1996. Comparative morphology of the ovipositor of some parasitic Hymenoptera in relation to characteristics of their hosts. Can. Entomol. 128, 413-433.

Nacro, S., Nénon, J.P., 2009. Comparative study of the morphology of the ovipositor of 
Platygaster diplosisae (Hymenoptera: Platygasteridae) and Aprostocetus procerae (Hymenoptera: Eulophidae) two parasitoids associated with the African rice gall midge, Orseolia oryzivora (Diptera: Cecidomyiidae). Psyche 2009, 1-7.

Pellmyr, O., Leebens-Mack, J., Huth, C.J., 1996. Non mutualistic yucca moths and their evolutionary consequences. Nature 380, 155-156.

Peng, Y.Q., Yang, D.R., Duang, Z.B., 2005. The population dynamics of a non-pollinating fig wasp on Ficus auriculata at Xishuangbanna, China. J. Trop. Ecol. 21, 581-584.

Peng, Y.Q., Duan, Z.B., Yang, D.R., Rasplus, J.Y., 2008. Co-ocurrence of two Eupristina species on Ficus altissima in Xishuangbann, SW China. Symbiosis 45, 9-14.

Peters, R.S., Krogmann, L., Mayer, C., Donath, A., Gunkel, S., Meusemann, K., Kozlov, A., Podsiadlowski, L., Petersen, M., Lanfear, R., Diez, P.A., Heraty, J., Kjer, K.M., Klopfstein, S., Meier, R., Polidori, C., Schmitt, T., Liu, S.L., Zhou, X., Wappler, T., Rust, J., Misof, B., Niehuis, O., 2017. Evolutionary history of the Hymenoptera. Curr. Biol. 27, 1013-1018.

Quicke, D.L.J., Fitton, M.G., Tunstead, J.R., Ingram, S.M., Gaitens, P.V., 1994. Ovipositor structure and relationships within the Hymenoptera, with special reference to the Ichneumonoidea. J. Nat. Hist. 28, 635-682.

Quicke, D.L., Fitton, M., Harris, J., 1995. Ovipositor steering mechanisms in Braconid wasps. J. Hymenopt. Res. 4, 110-120.

Quicke, D.L.J., Le Ralec, A., Vilhelmsen, L., 1999. Ovipositor Structure and Function in the Parasitic Hymenoptera with an Exploration of New Hypothesis. Atto dell'Accademia Nazionale Italiana di Entomologia Rendiconti, pp. 197-239.

R Development Core Team, 2015. R: a Language and Environment for Statistical Computing. R Foundation for Statistical Computing.

Revell, L., 2010. Phylogenetic signal and linear regression on species data. Methods Ecol. Evol. $1,319-329$.

Revell, L., 2012. Phytools: phylogenetic Tools for comparative biology (and other things). Methods Ecol. Evol. 3, 217-223.

Revell, L., 2013. Two new graphical methods for mapping trait evolution on phylogenies. Methods Ecol. Evol. 4, 754-759.

Ronquist, F., 1999. Phylogeny, classification and evolution of the Cynipoidea. Zool. Scripta 28, 139-164.

Schluter, D., 2000. The Ecology of Adaptive Radiation. Oxford University Press, Oxford. Sharkey, M.J., 2007. Phylogeny and classification of Hymenoptera. Zootaxa 1668, 521-548.

Tzeng, H.Y., Tseng, L.J., Ou, C.H., Lu, K.C., Lu, F.Y., Chou, L.S., 2008. Confirmation of the parasitoid feeding habit in Sycoscapter, and their impact on pollinator abundance in Ficus formosana. Symbiosis 45, 129-134.

Tzeng, H.Y., Ou, C.H., Lu, F.Y., Bain, A., Chou, L.S., Kjellberg, F., 2014. The effect of fig wall thickness in Ficus erecta var. beecheyana on parasitism. Acta Oecol 57, 38-43.

Verkerke, W., 1986. Anatomy of Ficus ottoniifolia (Moraceae) syconia and its role in the figfig wasp symbiosis. Proc. Kon. Ned. Akad. Wetensch., Ser. C 89, 443-469. 
Verkerke, W., 1987. Syconial anatomy of Ficus asperifolia (Moraceae), a gynodioecious tropical fig. Proc. Kon. Ned. Akad. Wetensch., Ser. C 90, 461-492.

Verkerke, W., 1989. Structure and function of the fig. Experientia 45, 612-622. Vilhelmsen, L., 2000. The ovipositor apparatus of basal Hymenoptera (Insecta): phylogenetic implications and functional morphology. Zool. Scr. 29, 319-345.

Vilhelmsen, L., Turrisi, G.F., 2011. Per arborem ad astra: morphological adaptations to exploiting the woody habitat in the early evolution of Hymenoptera. Arthropod Struct. Dev. 40, 2-20.

Vincent, J.F.V., King, M.J., 1996. The mechanism of drilling by wood wasp ovipositors. Biomimetics 3, 187-201.

Wang, R.W., Zheng, Q., 2008. Structure of a fig wasp community: temporal segregation of oviposition and larval diets. Symbiosis 45, 113-116.

Weiblen, G.D., 2002. How to be a fig wasp. Annu. Rev. Entomol. 47, 299-330.

Weltz, C.E., Vilhelmsen, L., 2014. The saws of sawflies: exploring the morphology of the ovipositor in Tenthredinoidea (Insecta: Hymenoptera), with emphasis on Nematinae. J. Nat. Hist. 48, 133-183.

Zhen, W.Q., Huang, D.W., Xiao, J.H., Yang, D.R., Zhu, C.D., Xiao, D., 2005. Ovipositor length of three Apocrypta species: effect on oviposition behaviour and correlation with syconial thickness. Phytoparasitica 33, 113-120. 